\section{PENGARUH ROA, CURRENT RATIO DAN QUICK RATIO TERHADAP RETURN SAHAM PT ASTRA AGRO LESTARI TBK PERIODE 2007 - 2017}

\author{
Agung Fajar Ilmiyono \\ Fakultas Ekonomi Universitas Pakuan \\ E-mail: agung.fajar@unpak.ac.id
}

Pengaruh ROA,

CR dan Quick

Ratio terhadap

Return Saham PT

Astra Agro

Lestari Tbk

Periode 2007 -

2017

278

\section{ABSTRACT}

Financial ratios are used to assess management performance in a period of reaching the target as determined. The purpose of this study is (1) to find out how much the partial influence of roa, cr and quick ratio have on stock returns on PT Astra Agro Lestari Tbk for the period 2007-2017. (2) to find out how much influence together returns on assets, current ratio and quick ratio to stock returns on PT Astra Agro Lestari Tbk for the period 2007-2017. The analytical method used in this study is descriptive statistics. Data was tested using E-Views 10. Partial testing with the t test gets the return on assets and the current ratio does not significantly influence stock returns. Whereas the quick quick ratio has a significant effect on stock returns. Simultaneous test results with f test, namely roa, cr and quick ratio together do not significantly influence stock returns.

Keywords: Return On Asset, Current Ratio, Quick Ratio, Return Saham.

\section{PENDAHULUAN}

Pasar modal dianggap sebagai salah satu instrumen ekonomi yang sangat penting. Hal ini karena pasar modal membantu pihak yang membutuhkan dana (borrower) untuk mendapatkan dana dan pihak yang kelebihan dana (lender) untuk dapat menginvestasikan dananya. Lender dapat memperoleh return dari penyerahan dana tersebut sedangkan borrower dapat segera menggunakan dana tersebut untuk kepentingan usahanya. Dengan demikian, dapat dikatakan bahwa pasar modal merupakan instrumen keuangan yang dapat memobilisasi dana dari masyarakat ke sektor yang produktif. Investor dapat mengalokasikan dananya secara efisien melalui pasar modal dengan memilih alternatif investasi yang memberikan return yang optimal.

Kinerja keuangan suatu perusahaan dapat menjadi salah satu sumber informasi bagi investor sebelum menentukan kuputusan berinvestasi, misalnya untuk mengetahui tingkat keuntungan tertinggi dan risiko tertentu yang ada di suatu perusahaan. Investor cenderung akan tertarik pada perusahaan yang memiliki kinerja keuangan yang cukup baik.

Oleh karena itu, dapat dikatakan bahwa kinerja keuangan perusahaan merupakan salah satu faktor yang mempengaruhi return saham. Hal ini seperti yang disampaikan oleh Samsul (2006) bahwa terdapat beberapa faktor yang mempengaruhi return saham yaitu dari faktor makro dan mikro. Faktor secara makro antara lain tingkat suku bunga domestik, tingkat inflasi, kurs valuta asing, dan kondisi perekonomian internasiona. Selain itu faktor mikro terdiri dari rasio di dalam perusahaan yaitu rasio likuiditas, rasio probabilitas, dan rasio keuangan lainnya.

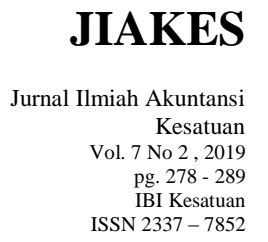

Submitted: MEI 2019

Accepted: OKTOBER 2019 \section{西}


Pengaruh ROA, CR dan Quick Ratio terhadap Return Saham PT Astra Agro Lestari Tbk Periode 2007 2017

$\underline{279}$
Dalam penelitian ini rasio yang digunakan adalah Return On Asset (ROA), Current Ratio (CR) dan Quick Ratio (QR). Ketiga rasio tersebut dipilih sebagai indikator untuk mengetahui apakah memiliki pengaruh baik secara simultan maupun parsial terhadap return saham PT Astra Agro Lestari Tbk. Beberapa penelitian terdahulu terkait telah banyak dilakukan. Namun, terdapat perbedaan terhadap hasil penelitian terdahulu mengenai Returnn On Asset, Current Ratio dan Quick Ratio serta pengaruhnya terhadap return saham, namun terdapat ketidak konsistenan terhadap hasil penelitian terdahulu, hal ini membuat peneliti tertarik untuk menganalisa kembali mengenai pengaruh Return On Asset, Current Ratio dan Quick Ratio tersebut terhadap return saham dengan menggunakan data 10 tahun terakhir pada PT Astra Agro Lestari Tbk.

Berikut disajikan grafik pergerakan Return On Asset, Current Ratio, Quick Ratio serta return saham PT Astra Agro Lestari Tbk periode 2007-2017:

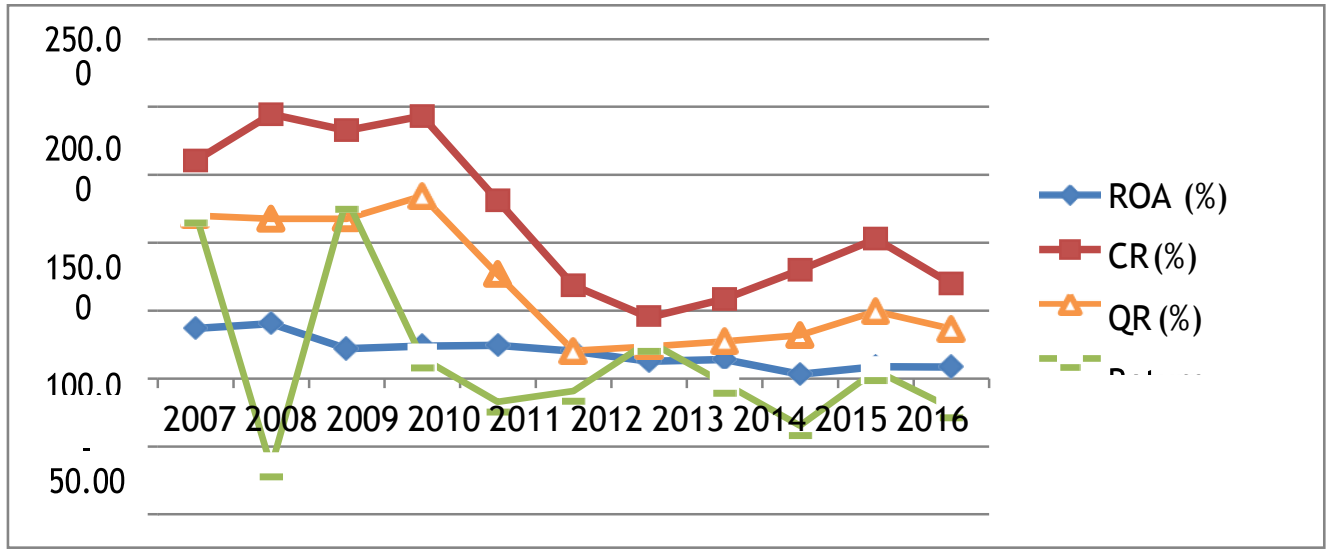

Sumber: Laporan Keuangan Diolah, 2018

Gambar 1: Grafik ROA, CR dan QR pada AALI Periode 2007-2017

Berdasarkan latar belakang masalah diatas, terdapat suatu kesenjangan ( $g a p$ ) atau fenomena gap dan research gap, dimana teori yang ada dengan keadaan berbeda sehingga membutuhkan penelitian lanjutan mengenai masalah tersebut. Fenomena gap yang terjadi ada pada tahun 2012, Return On Asset, Current Ratio dan Quick Ratio mengalami penurunan, namun yang terjadi justru return saham meningkat, serta fenomena gap yang terjadi ada pada tahun 2014, Return On Asset, Current Ratio dan Quick Ratio meningkat, namun yang terjadi justru return saham mengalami penurunan. Hal ini berbeda dengan teori yang menyatakan bahwa apabila Return On Asset, Current Ratio dan Quick Ratio meningkat maka return saham akan mengalami peningkatan begitupun sebaliknya.

Selain terdapat fenomena gap seperti yang telah diuraikan diatas, terdapat pula research gap atau inkonsistensi peneliti satu dengan peneliti lainnya. Berdasarkan penelitian terdahulu banyak perbedaan mengenai pengaruh Return On Asset, Current Ratio dan Quick Ratio terhadap return dari berbagai kelompok saham yang diteliti, sehingga belum ada kepastian atau kejelasan tentang faktor-faktor yang dominan mempengaruhi return saham. Sehingga dengan hal tersebut maka perlu untuk pengembangan penelitian terdahulu tentang pengaruh Return On Asset, Current Ratio dan Quick Ratio terhadap return saham.

Penelitian ini bertujuan untuk menguji pengaruh variabel Return On Asset (ROA), Current Ratio (CR) dan Quick Ratio (QR) terhadap return saham pada PT Astra Agro Lestari Tbk periode 2007-2017. 
TINJAUAN PUSTAKA

Lukman Syamsudin (2013:63) menyatakan bahwa ROA merupakan sebuah ukuran kemampuan perusahaan secara keseluruhan untuk dapat menghasilkan keuntungan melalui jumlah keseluruhan aktiva yang dimiliki perusahaan. Lebih lanjut Lukman Syamsudin menjelaskan bahwa (2013: 74) ROA adalah laba bersih perusahaan sesudah dikurangi pajak dibagi dengan total aktiva perusahaan. ROA dapat diformulasikan sebagai berikut:

ROA $=\frac{\text { NIAT }}{\text { Total Asset }} \times 100$

\begin{tabular}{|ll|}
\hline NIAT & $=\begin{array}{l}\text { Net Income After Tax } \\
\text { (laba bersih sesudah pajak) } \\
\text { Total Aset perusahaan } \\
\text { pada periode laporan akhir } \\
\text { tahun }\end{array}$ \\
\hline
\end{tabular}

Berdasarkan penelitian terdahulu dari Edhi Asmirantho, dkk (2016) dalam penelitiannya yang berjudul "Pengaruh Kinerja Keuangan dan Makroekonomi terhadap Return Saham pada subsektor makanan dan minuman periode 2011-2015" dan hasil penelitian tersebut menunjukkan bahwa Return On Asset (ROA) berpengaruh negatif dan signifikan terhadap return saham. Hal ini berarti semakin tinggi Return On Asset (ROA) maka return saham akan turun atau semakin rendah Return On Asset (ROA) maka return saham akan naik.

Sedangkan penelitian yang dilakukan oleh Singgih Ariyo dan Ismani (2013) dengan judul "Pengaruh EVA, MVA, ROA Terhadap Return Saham Perusahaan Makanan Minuman di BEI" dan hasil penelitian tersebut menunjukkan bahwa Return On Asset secara parsial berpengaruh positif dan signifikan terhadap Return Saham. Hal ini berarti semakin tinggi Return On Asset (ROA) maka return saham juga akan semakin tinggi.

Menurut Kasmir (2015:134), Current Ratio merupakan ukuran yang menunjukkan kemampuan suatu perusahaan untuk dapat menyelesaikan hutang jangka pendek atau utang yang segera jatuh tempo pada saat ditagih. Current ratio dapat didefinisikan dengan jumlah aktiva lancar perusahaan yang tersedia untuk menutupi kewajiban jangka pendek yang segera jatuh tempo.

Current Ratio (CR) dapat diformulasikan sebagai berikut :

$\mathrm{CR}=\underset{\text { Utang Lancar }}{\mathrm{Aktiva} \text { Lancar }} \mathbf{1 0 0}$

Hasil penelitian dari Edhi Asmirantho, dkk (2016) dalam penelitiannya yang berjudul "Pengaruh Kinerja Keuangan dan Makroekonomi terhadap Return Saham pada subsektor makanan dan minuman periode 2011-2015" dan hasil penelitian tersebut menunjukkan bahwa Current Ratio (CR) berpengaruh negatif dan signifikan terhadap
Pengaruh ROA, CR dan Quick Ratio terhadap Return Saham PT Astra Agro Lestari Tbk Periode 2007 2017 
return saham. Hal ini berarti semakin tinggi Current Ratio (CR) maka return saham akan turun atau bergerak sebaliknya.

Pengaruh ROA, CR dan Quick Ratio terhadap Return Saham PT Astra Agro Lestari Tbk Periode 2007 2017

Sedangkan berdasarkan penelitian yang dilakukan oleh Darmawan, dkk (2014) dalam mengenai "Pengaruh ROI, EVA dan Likuiditas Saham terhadap Return Saham pada Sektor Keuangan yang Go Public" menghasilkan simpulan bahwa Current Ratio (CR) berpengaruh positif signifikan terhadap return saham. Hal ini berarti semakin tinggi Current Ratio (CR) maka return saham juga akan semakin tinggi.

Quick Ratio (QR) menurut Lukman Syamsudin (2013:68) merupakan sebuah ukuran kemampuan perusahaan untuk dapat memenuhi kewajiban-kewajiban atau utang lancar dengan aktiva yang lebih likuid.

Quick Ratio (QR) dapat diformulasikan sebagai berikut:

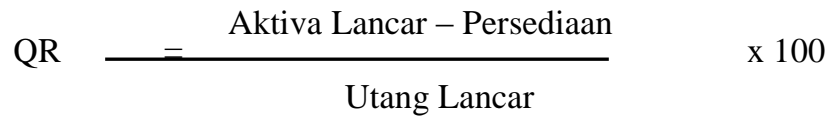

Penelitian dari Zunaini dkk (2016) menunjukkan bahwa Quick Ratio (CR) memiliki pengaruh positif dan signifikan terhadap return saham. Hal ini berarti semakin tinggi Quick Ratio (QR) maka return saham akan naik dan semakin rendah Quick Ratio (QR) maka return saham akan turun. Lusi Puspitasari (2013) dalam penelitiannya mengenai "Analisi Pengaruh Kinerja Keuangan Terhadap Return Saham pada Perusahaan Manufaktur yang Terdaftar di BEI" menghasilkan simpulan bahwa Quick Ratio (QR) berpengaruh negatif signifikan terhadap return saham. Hal ini berarti semakin tinggi Quick Ratio (QR) maka return saham akan semakin rendah atau bergerak sebaliknya.

Ang (1997) menyatakan bahwa tingkat keuntungan yang dapat dinikmati oleh pemodal dari suatu investasi saham yang dilakukan disebut sebagai return saham. Begitu pula seperti yang dinyatakan oleh Jogiyanto (2005) bahwa return merupakan hasil yang diperoleh dari investasi. Return saham tersebut dapat berupa return yang sudah terjadi atau disebut return realisasian dan return yang belum terjadi tetapi diharapkan terjadi di masa dating atau disebut return ekspektasian. Return relisasian (realized return) dapat dihitung dengan menggunakan data historis return saham. Return ekspektasian juga ditentukan melalui return realisasian atau return historis. Return expektasian (expected return) adalah return yang diharapkan akan diperoleh oleh investor dimasa mendatang. Seorang investor dihadapkan dengan ketidak pastian antara return yang diperoleh dengan risiko yang dihadapinya. Semakin besar return yang diharapkan akan diperoleh dari investsai, semakin besar pula risikonya. Sehingga dikatakan ada hubungan positif antara return ekspektasian dengan risiko. Semakin tinggi return ekspektasian, semakin tinggi risiko yang harus ditanggung.

Berikut formula Return Saham menurut teori pasar:

Return $=\frac{\text { Harga Saham Periode } \mathrm{t}-\text { Harga Saham Periode } \mathrm{t}-1}{\text { Harga Saham Periode } \mathrm{t}-1} \quad \times 100$

Salah satu bidang investasi yang cukup menarik namun berisiko tinggi adalah investasi saham. Menurut (Gendro dan Hadri, 2017) menerbitkan saham merupakan salah satu pililhan perusahaan ketika memutuskan untuk pendanaan pada perusahaan.

Penelitian Asmirantho, dkk (2016) menunjukkan bahwa Current Ratio (CR) dan Return On Asset (ROA) berpengaruh negatif dan signifikan terhadap return saham. Sedangkan berdasarkan penelitian yang dilakukan oleh Zunaini dkk (2016) menghasilkan 
simpulan bahwa Return On Asset (ROA), Current Ratio (CR) dan Quick Ratio (QR) berpengaruh positif dan signifikan terhadap return saham. Dengan demikian dapat disimpulkan bahwa dengan adanya peningkatan nilai Return On Asset (ROA), Current Ratio (CR) dan Quick Ratio (QR) maka cenderung akan terjadi peningkatan juga pada nilai return saham atau setiap penurunan nilai Return On Asset (ROA), Current Ratio (CR) dan Quick Ratio (QR) maka akan terjadi pula penurunan pada nilai return saham.

\section{METODE PENELITIAN}

Jenis penelitian yang digunakan dalam penelitian ini adalah jenis atau bentuk penelitian verifikatif dengan metode Explanatory Survey. Penelitian verifikatif dengan metode Explanatory Survey bertujuan untuk menguji hipotesis, yang umumnya merupakan penelitian yang menjelaskan fenomena dalam bentuk hubungan antar variabel. Penelitian ini dilakukan untuk mengetahui pengaruh Return On Assets (ROA), Current Ratio (CR) dan Quick Ratio (QR) terhadap Return Saham pada PT Astra Agro Lestari Tbk periode 2007-2017.

Objek penelitian dalam penelitian ini adalah variabel-variabel yang meliputi Return On Assets (ROA), Current Ratio (CR), Quick Ratio (QR) serta pengaruhnya terhadap Return Saham. Untuk memperoleh data dan informasi yang diperlukan maka penulis melakukan penelitian atas variabel-variabel tersebut pada PT Astra Agro Lestari Tbk periode 2007-2017. Unit analis yang digunakan dalam penelitian ini adalah laporan keuangan pada PT Astra Agro Lestari Tbk periode 2007-2017.

Jenis data yang diteliti adalah data kuantitatif. Selanjutnya jenis sumber data penelitian ini menggunakan data sekunder. Adapun data dan sumber data diperoleh dari website yaitu: (http://www.astra- agro.co.id/) dan (http://www.idx.co.id/).

Tabel 1: Operasionalisasi Variabel

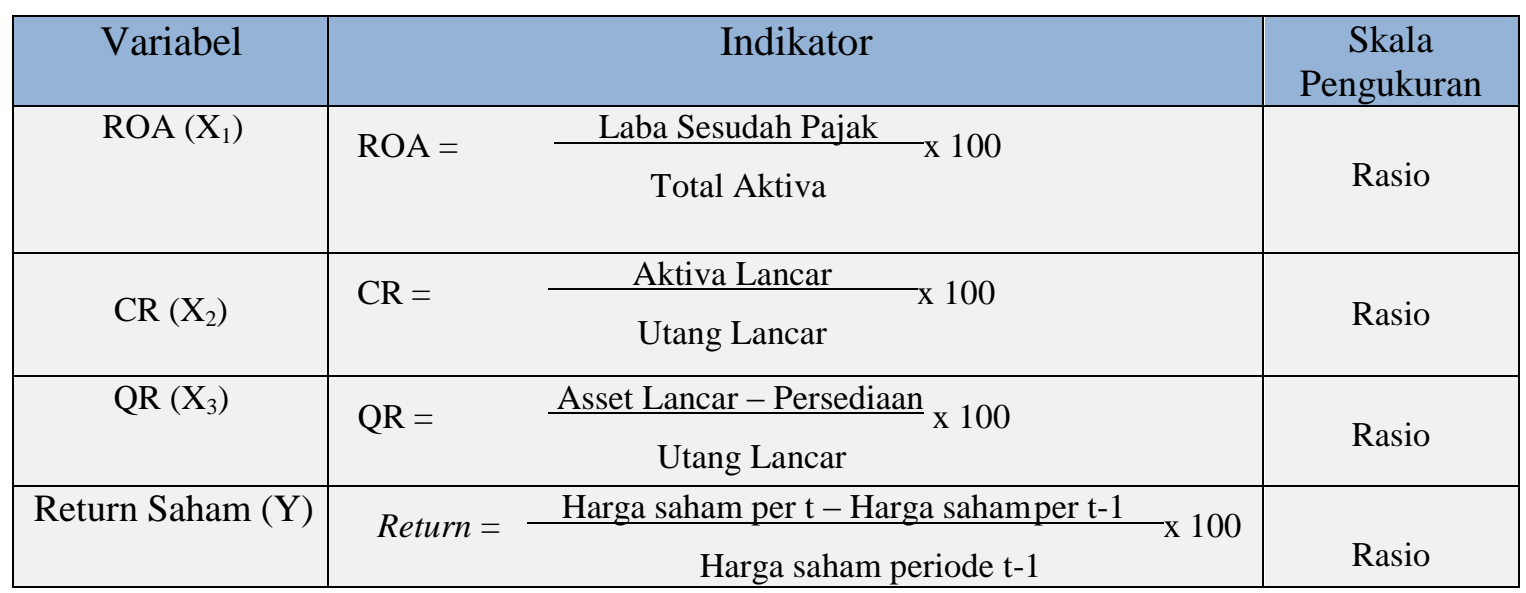

Metode penarikan sampel yang digunakan penulis dalam penelitian ini adalah purposive sampling. Prosedur pengumpulan data dilakukan dengan cara: riset kepustakaan dan riset internet.

Analisis dalam penelitian ini berdasarkan jenisnya merupakan analisis kuantitatif karena dalam penelitian ini menguji hipotesis menggunakan uji statistik. Metode analisis yang digunakan dalam penelitian ini adalah analisis statistika inferensial yaitu regresi dan korelasi menggunakan software E-views. Penelitian ini menggunakan analisis statistika
Pengaruh ROA, CR dan Quick Ratio terhadap Return Saham PT Astra Agro Lestari Tbk Periode 2007 2017 
parametrik karena menggunakan data berupa rasio atau berdasarkan sifatnya adalah data kuantitatif dan digunakan dalam analisis hubungan antar variabel.

Pengaruh ROA, CR dan Quick

Ratio terhadap

Return Saham

PT Astra Agro

Lestari Tbk

Periode 2007 -

2017

283

\section{HASIL DAN PEMBAHASAN}

Regresi Linier Berganda

Berikut ini merupakan hasil reglesi linier berganda untuk penelitian ini dengan ROA, CR dan QR sebagai variabel independen serta return saham sebagai variabel dependennya.:

Tabel 2. Analisis Regresi Linier Berganda

\begin{tabular}{|l|c|c|c|c|c|}
\hline \multicolumn{1}{|c|}{ Variable } & Coefficient & $\begin{array}{c}\text { Std. } \\
\text { Error }\end{array}$ & t-Statistic & Prob. & Keterangan \\
\hline C & 62.02887 & 57.45069 & 1.079689 & $\underline{0.3161}$ & \\
\hline ROA & -1.018666 & 2.270866 & -0.448581 & $\underline{0.6673}$ & Tidak Berpengaruh \\
\hline CR & -252.7605 & 145.6188 & -1.735768 & $\underline{0.1262}$ & Tidak Berpengaruh \\
\hline QR & 388.8284 & 188.5074 & 2.062669 & $\underline{0.0781}$ & Berpengaruh \\
\hline & & & & & \\
\hline Prob(F-statistic) & $\underline{0.234013}$ & & & & Tidak Berpengaruh \\
\hline
\end{tabular}

Sumber: Data diolah dengan E-Views 10, 2019

Pada tabel 2 terlihat hasil pengujian analisis regresii linier berganda. Variabel independen yang digunakan dalam penelitian ini yaitu $\mathrm{ROA}\left(\mathrm{X}_{1}\right), \mathrm{CR}\left(\mathrm{X}_{2}\right)$, dan $\mathrm{QR}$ $\left(\mathrm{X}_{3}\right)$ kemudian variabel dependen yaitu return saham $(\mathrm{Y})$. Dari tabel tersebut dapat disimpulkan bahwa:

1. Nilai ROA 0,6673 atau lebih dari $10 \%$ maka berarti ROA secara parsial tidak berpengaruh terhadap return saham.

2. Nilai CR 0,1262 atau lebih dari $10 \%$ maka berarti CR secara parsial tidak berpengaruh terhadap return saham.

3. Nilai QR 0,0781 atau kurang dari 10\% maka berarti QR secara parsial berpengaruh terhadap return saham.

4. Nilai ROA, CR dan QR secara bersama adalah 0,234 atau lebih dari 10\% maka ROA CR QR secara simultan tidak berpengaruh terhadap return saham.

\section{Uji Asumsi Klasik}

Uji asumsi klasik terpenuhi jika dihasilkan estimator yang sesuai Best Linear Unbiased Estimator (BLUE), yang berarti model regresi dapat digunakan sebagai alat estimasi penelitian (Ghozali, 2016). Pengujian asumsi klasik ini menggunakan empat pengujian yaitu uji normalitas, uji multikolinearitas, uji heteroskedastisitas, dan uji autokorelasi.

1. Uji Normalitas

Uji asumsi normalitas ini dilakukan dengan menggunakan uji Jarque-Bera. Hipotesis dari uji normalitas ini adalah $\mathrm{H} 0=$ berdistribusi normal dan $\mathrm{H} 1$ = berdistribusi tidak normal. Uji Normalitas pada penelitian ini dapat dilihat pada hasil uji dibawah ini. 
4

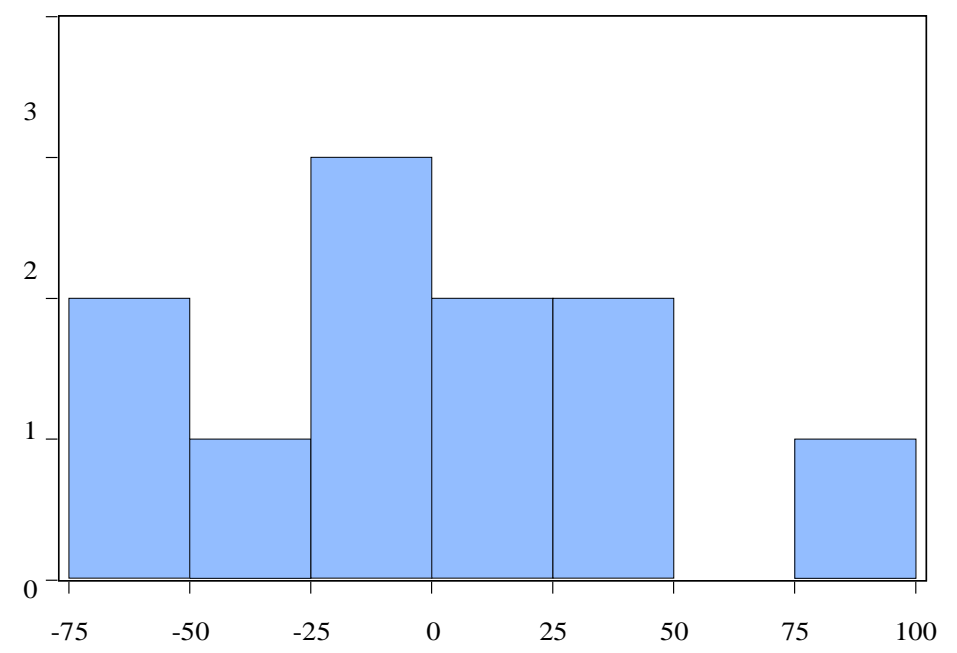

Sumber: Data diolah dengan E-Views 10, 2019
Series: Residuals

Sample 20072017

Observations 11

Mean

Median

$-6.33 e-14$

Maximum

$-9.691964$

Minimum

Std. Dev.

96.59395

$-56.58421$

46.01983

Skewness $\quad 0.682757$

Kurtosis

2.763031

Jarque-Bera

Probability
Pengaruh ROA,

CR dan Quick

Ratio terhadap

Return Saham

PT Astra Agro

Lestari Tbk

Periode 2007 -

2017

Gambar 2: Hasil Uji Normalitas

Keputusan terdistribusi normal tidaknya residual secara sederhana dengan membandingkan nilai Probabilitas JB (Jarque- Bera) hitung dengan tingkat alpha 0,10 (10\%). Apabila Prob. JB hitung lebih besar dari 0,10 maka dapat disimpulkan bahwa residual terdistribusi normal dan sebaliknya, apabila nilainya lebih kecil maka tidak cukup bukti untuk menyatakan bahwa residual terdistribusi normal. Nilai Prob. JB hitung sebesar $0.6439>0,10$ sehingga dapat disimpulkan bahwa residual terdistribusi normal yang artinya asumsi klasik tentang kenormalan telah dipenuhi.

2. Uji Heteroskedastisitas

Uji heteroskedastisitas digunakan untuk mengetahui jika varian tidak konstan dan terjadi hubungan yang kuat antar residual. Heteroskedastisitas diuji dengan menggunakan uji LR. Yaitu dengan meregresikan variabel-variabel bebas terhadap residual absolut dengan hipotesis $\mathrm{H}_{0}=$ homosedastisitas dan $\mathrm{H}_{1}=$ heteroskedastisitas.

Tabel 3: Hasil Uji Heteroskedastisitas

\begin{tabular}{|l|c|c|c|c|}
\hline \multicolumn{1}{|c|}{ Variable } & Coefficient & Std. Error & t-Statistic & Prob. \\
\hline C & -1454.304 & 2522.726 & -0.576481 & $\underline{0.5823}$ \\
\hline ROA & -81.57560 & 99.71634 & -0.818077 & $\underline{0.4403}$ \\
\hline CR & 4832.228 & 6394.291 & 0.755710 & $\underline{0.4745}$ \\
\hline QR & -979.2197 & 8277.580 & -0.118298 & $\underline{0.9092}$ \\
\hline
\end{tabular}

Sumber: Data diolah dengan E-Views 10, 2019

Hasil pengujian yang dilakukan terlihat bahwa nilai probabilitas ROA CR dan QR 
Pengaruh ROA, CR dan Quick Ratio terhadap Return Saham PT Astra Agro Lestari Tbk

Periode 2007 2017

$\underline{285}$ lebih dari 10\% sehingga dapat disimpulkan bahwa model regresi tidak mengalami masalah heteroskedastisitas.

3. Uji Multikolinearitas

Masalah multikolinearitas dapat diketahui dari koefisien korelasi antara masingmasing variabel bebas. Apabila koefisien $>10$ maka dalam model regresi terjadi multikolinearitas dan begitu pula sebaliknya apabila koefisien $<10$ maka variabel bebas terbebas dari multikolinearitas. Koefisien korelasi pada penelitian ini dapat dapat dilihat pada tabel dibawah.

Tabel 4: Hasil Uji Multikolinearitas

\begin{tabular}{|l|c|c|c|}
\hline & ROA & CR & QR \\
\hline ROA & 1.0000000000000000 & 0.7416662592830230 & 0.7554705898443714 \\
\hline CR & 0.7416662592830230 & 1.0000000000000000 & 0.9780991711129854 \\
\hline QR & 0.7554705898443714 & 0.9780991711129854 & 1.0000000000000000 \\
\hline
\end{tabular}

Sumber: Data diolah dengan E-Views 10, 2019

Dari tabel terlihat bahwa nilai koefisien korelasi $<8 \%$, dengan demikian dapat disimpulkan variabel dalam model regresi yang digunakan dalam penelitian ini tidak terdapat multikolinearitas.

\section{Uji Autokorelasi}

Uji autokorelasi digunakan untuk mengetahui apakah terdapat korelasi antara kesalahan pengganggu pada periode $(\mathrm{t})$ dengan kesalahan pengganggu pada periode (t-1). Metode yang digunakan dalam penelitian ini adalah metode uji Durbin-Watson dengan hipotesis $\mathrm{H} 0$ = tidak adanya korelasi dan $\mathrm{H} 1$ = ada korelasi. Adapun Hasil regresi DurbinWatson dapat dilihat pada tabel regresi dibawah.

Tabel 5: Hasil Uji Autokorelasi

\begin{tabular}{|l|c|}
\hline \multicolumn{1}{|c|}{ Keterangan } & Hasil \\
\hline Durbin-Watson stat & 3.082579 \\
\hline
\end{tabular}

Sumber: Data diolah dengan E-Views 10, 2019

Secara grafis dapat digambarkan dengan gambar grafik di bawah ini.

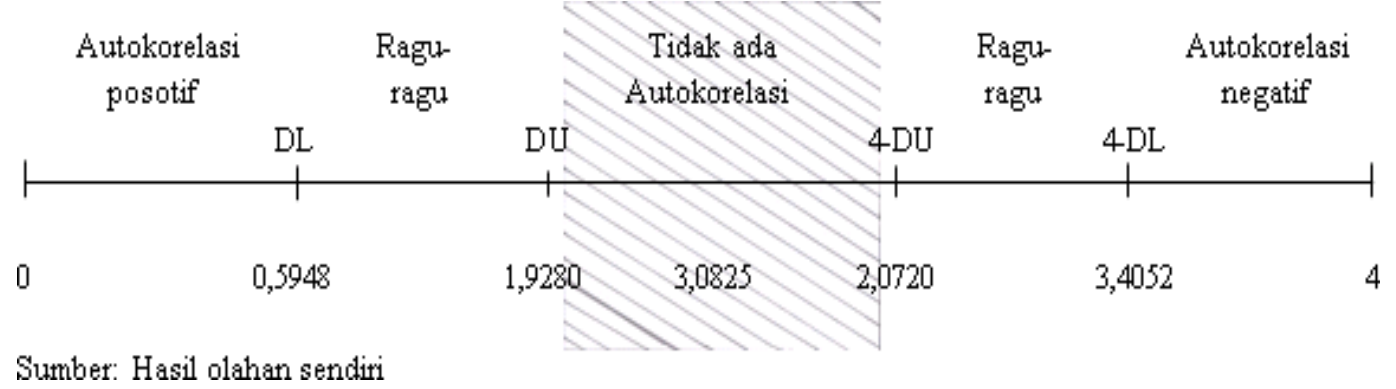

Gambar 3: Grafik Uji Tabel Durbin-Watson

Nilai D-W pada hasil regresi Durbin-Watson menunjukkan bahwa nilai sebesar 3,0825 yang akan dibandingkan dengan DU dan DL. Nilai DW hitung kemudian 
dibandingkan dengan kriteria penerimaan atau penolakan yang akan dibuat dengan nilai DL dan DU yang ditentukan berdasarkan jumlah variabel bebas dalam model regresi (k) dan jumlah sampelnya $(\mathrm{n})$. Jika nilai $0<\mathrm{D}<\mathrm{DL}$, maka dapat dinyatakan bahwa ada masalah autokorelasi positif dan sebaliknya jika nilai $0<\mathrm{D}>\mathrm{DL}$ maka menerima hipotesis yaitu tidak ada masalah autokorelasi positif. Nilai dL dan dU dapat dilihat pada Tabel DW dengan tingkat signifikansi (error) $10 \%(\mathrm{a}=0,10)$. Tabel Durbin-Watson menunjukkan bahwa nilai $\mathrm{DL}=0,5948$ dan nilai $\mathrm{DU}=1,9280$ yang berarti nilai $\mathrm{DW}<4$-DU dan $>\mathrm{DU}$ sehingga menerima hipotesis yaitu tidak ada masalah autokorelasi positif.

\section{Uji Koefisien Determinasi (Adjusted)}

Koefisien determinasi menjelaskan variasi pengaruh variable-variabel bebas terhadap variable terikatnya. Atau dapat pula dikatakan sebagai proporsi pengaruh seluruh variable bebas terhadap variabel terikat. Adapun hasil koefisien determinasi $\left(\mathrm{R}^{2}\right)$ dapat dilihat pada tabel dibawah ini :

Tabel 6: Hasil Uji Koefisien Determinasi

\begin{tabular}{|l|c|}
\hline \multicolumn{1}{|c|}{ Keterangan } & Hasil \\
\hline R-squared & 0.436103 \\
\hline Adjusted R-squared & 0.194433 \\
\hline
\end{tabular}

Sumber: Data diolah dengan E-Views 10, 2019

Nilai R-squared pada tabel di atas sebesar 0.4361 yang menunjukkan bahwa proporsi pengaruh variabel ROA, CR dan QR terhadap return saham sebesar $43.61 \%$ sedangkan sisanya $56.39 \%(100 \%$ - 43.61\%) dipengaruhi oleh variabel lain yang tidak ada didalam model regresi.

Uji Koefisien Regresi Parsial (Uji t)

Hasil uji t dapat dilihat pada tabel dibawah. Apabila nilai probilitas t hitung (yang ditunjukkan pada nilai probilitas) lebih kecil dari tingkat kesalahan (alpha) 0,10 maka dapat dikatakan bahwa variabel bebas berpengaruh signifikan terhadap variable dependen, sedangkan apabila nilai probilitas t hitung lebih besar dari tingkat kesalahan 0,10 maka dapat dikatakan bahwa variabel independen tidak berpengaruh signifikan terhadap variabel dependen.

Tabel 7: Hasil Uji Koefisien Regresi Parsial

\begin{tabular}{|l|c|c|c|}
\hline \multicolumn{1}{|c|}{ Variabel } & Probabilitas & Probabilitas Kritis (a) & Keterangan \\
\hline ROA & 0.66 & 0.10 & Tidak Berpengaruh \\
\hline CR & 0.12 & 0.10 & Tidak Berpengaruh \\
\hline QR & 0.07 & 0.10 & Berpengaruh \\
\hline
\end{tabular}

Sumber: Data diolah dengan E-Views 10, 2019

Hasil regresi yang telah dilakukan dapat dilihat dari tabel diatas yang menunjukkan hubungan pengaruh Return On Asset, Current Ratio dan Quick Ratio terhadap return saham sebagai berikut:

$\mathrm{H}_{1}$ : Return On Asset tidak berpengaruh signifikan terhadap variabel return saham pada PT Astra Agro Lestari Tbk periode 2007-2017. Nilai probilitas t hitung dari variabel Return On Asset sebesar 0,66 yang lebih besar dari 0,10 sehingga Return 
Pengaruh ROA, CR dan Quick Ratio terhadap Return Saham PT Astra Agro Lestari Tbk Periode 2007 2017

\section{$\underline{287}$}

On Asset tidak berpengaruh signifikan terhadap return saham. Hasil penelitian ini sejalan dengan Nur Tri Kadarini (2013) dan Andi Nadhil Asyrafi, Norita, dan Vaya Juliana Dillak (2017). Namun, hasil penelitian tidak sejalan dengan hipotesis. Sehingga H1 bahwa Return On Asset berpengaruh signifikan terhadap return saham ditolak.

$\mathrm{H}_{2}$ : Current Ratio tidak berpengaruh signifikan terhadap variabel return saham pada PT Astra Agro Lestari Tbk periode 2007-2017. Nilai probilitas t hitung dari variabel Current Ratio sebesar 0,12 yang lebih besar dari 0,10 sehingga Current Ratio tidak berpengaruh signifikan terhadap return saham. Hasil penelitian ini sejalan dengan Ihsan S. Basalama, Sri Murni, dan Jacky S.B. Sumarauw (2017). Namun, hasil penelitian tidak sejalan dengan hipotesis. Sehingga H2 bahwa Current Ratio berpengaruh signifikan terhadap return saham ditolak.

$\mathrm{H}_{3}$ : Quick Ratio berpengaruh signifikan terhadap variabel return saham pada PT Astra Agro Lestari Tbk periode 2007-2017. Nilai probilitas t hitung dari variabel Quick Ratio sebesar 0,07 yang lebih kecil dari 0,10 sehingga Quick Ratio berpengaruh signifikan terhadap return saham. Hasil penelitian ini sejalan dengan penelitian Lusi Puspitasari (2013) dan Elis Zunaini dan Ida Ayu Sri Brahmayanti (2016). Hasil penelitian mendukung hipotesis. Sehingga, H3 bahwa Quick Ratio berpengaruh signifikan terhadap return saham diterima.

\section{Uji Kecocokan Model (Uji F)}

Uji kecocokan model dapat diketahui dengan melihat nilai probilitas $\mathrm{F}$ hitung. Apabila nilai probilitas F hitung lebih kecil dari tingkat kesalahan (alpha) 0,10 (yang telah ditentukan) maka dapat dikatakan bahwa model regresi yang diestimasi cocok, sedangkan apabila nilai probilitas $\mathrm{F}$ hitung lebih besar dari tingkat kesalahan 0,10 maka dapat dikatakan bahwa model regresi yang diestimasi tidak cocok. Hasil uji F dapat dilihat pada tabel 8 di bawah ini.

Tabel 8: Hasil Uji Koefisien Kecocokan Model

\begin{tabular}{|l|r|c|c|}
\hline \multicolumn{1}{|c|}{ Keterangan } & Hasil & Perbandingan & Keputusan Akhir \\
\hline Prob F-Statistil & 0.23 & \multirow{2}{*}{ Prob F-Statistik > 0.10 } & Tidak Berpengaruh \\
\hline $\mathrm{a}=10 \%$ & 0.10 & & \\
\hline
\end{tabular}

Sumber: Data diolah dengan E-Views 10, 2019

Hasil regresi yang telah dilakukan dapat dilihat dari tabel diatas yang menunjukkan hubungan pengaruh Return On Asse, Current Ratio dan Quick Ratio terhadap return saham sebagai berikut:

$\mathrm{H}_{4}$ : Return On Asset, Current Ratio dan Quick Ratio tidak berpengaruh signifikan terhadap variabel return saham pada PT Astra Agro Lestari Tbk periode 2007-2017. Nilai probilitas (F-statistik) sebesar 0,23 lebih besar dari tingkat signifikansi 0,10 dan hasil penelitian tidak sejalan dengan hipotesis. Sehingga, H4 bahwa Return On Asset, Current Ratio dan Quick Ratio berpengaruh signifikan terhadap return saham ditolak dengan kata lain secara simultan variabel Return On Asset, Current Ratio dan Quick Ratio tidak berpengaruh secara signifikan terhadap variabel terikat return saham. 


\section{SIMPULAN}

Berdasarkan pembahasan dan analisis mengenai pengaruh Return On Asset (ROA), Current Ratio (CR) dan Quick Ratio (QR) terhadap return saham pada PT Astra Agro Lestari periode 2007-2017, maka diambil sintesa sebagai berikut:

1. Return On Asset (ROA) secara parsial tidak berpengaruh signifikan terhadap return saham pada PT Astra Agro Lestari Tbk periode 2007-2017.

2. Current Ratio (CR) secara parsial tidak berpengaruh signifikan terhadap return saham pada PT Astra Agro Lestari Tbk periode 2007-2017.

3. Quick Ratio (QR) secara parsial berpengaruh signifikan terhadap return saham pada PT Astra Agro Lestari Tbk periode 2007-2017.

4. Berdasarkan hasil pengujian secara simultan Return On Asset (ROA), Current Ratio (CR) dan Quick Ratio (QR) tidak berpengaruh signifikan terhadap variabel return saham pada PT Astra Agro Lestari Tbk periode 2007-2017.

Pengaruh ROA, CR dan Quick Ratio terhadap Return Saham PT Astra Agro Lestari Tbk Periode 2007 -

\section{DAFTAR PUSTAKA}

Abdullah, M. Faisal. (2007). Dasar-Dasar Manajemen Keuangan. Edisi Kedua. Cetakan Kelima. Penerbit: Universitas Muhammadiyah. Malang. Edisi 2018.Penerbit : Salemba Empat. Jakarta.

Ariyo, Singgih., dan Ismani. (2013). Pengaruh EVA, MVA, ROA Terhadap Return Saham Perusahaan Makanan Minuman di BEI. Jurnal Profita. 128-153.

Asmirantho, Edhi., dan dkk. (2016). Pengaruh Kinerja Keuangan dan Makroekonomi Terhadap Return Saham pada Subsektor Makanan dan Minuman Periode 20112015. JIMFE. Volume 2 No. 2

Ang, Robert., (1997). Buku Pintar Pasar Modal Indonesia. Edisi Pertama. Rineka Cipta. Jakarta.

Darmawan, Ketut Arya., Suwebdra, I Wayan., dan Susila, Gede Putu Agus Jana. (2014). Pengaruh ROI, EVA dan Likuiditas Saham Terhadap Return Saham pada Sektor Keuangan yang Go Public. E- JURNAL BUPGJM. Vol. 2.

Harahap, Sofyan Syafiri. (2011). Analisa Kritis Atas Laporan Keuangan. Edisi Kelima.Jakarta: PT Raja Grasindo Persada.

Harjito, Agus., dan Martono. (2007). Manajemen Keuangan, Yogyakarta, Ekonisia. Hery. (2013). Akuntansi Keuangan Menengah. Yogyakarta: CPAS. Ikatan Akuntan Indonesia. (1984). Prinsip- Prinsip Akuntansi Keuangan. IAI. Jakarta. Irmayanto, Juli., dkk. (2004). Bank dan Lembaga Keuangan. Jakarta: Universitas Trisakti. Jogiyanto. (2010). Teori Portofollio dan Analisis Investasi, Edisi Ketujuh Yogyakarta: BPEE.

Johanes dan Syahfirin . (2017). Pengantar Statistik Untuk Berbagai Bidang Ilmu, Rajawali Pers.

Kadarini, Nur Tri. (2013). Analisis Pengaruh Current Ratio, Debt to Equity Ratio, Quick Asset to Inventory Ratio dan Return On Asset Terhadap Return Saham. Jurnal Ekonomi. Tahun 2013.

Kasmir, (2015). Analisis Laporan Keuangan. Cetakan Kedelapan. Jakarta: PT Rajagrafindo Persada.

Lukman, Syamsudin. (2004). Manajemen Keuangan Perusahaan (Konsep Aplikasi Dalam 
Perencanaan, Pengawasan, dan Pengambilan Keputusan). Jakarta: PT.Raja Grafindo Persada.

Munawir. (2014). Analisis Laporan Keuangan.Yogyakarta : Edisi Empat, Liberty. Riyanto, Bambang. (2007). Dasar-Dasar Pembelanjaan Perusahaan. Yogyakarta: BPFE.

Pengaruh ROA, CR dan Quick

Ratio terhadap Return Saham PT Astra Agro Lestari Tbk

Periode 2007 2017

289
Puspitasari, Lusi. 2013. Analisis Pengaruh Kinerja Keuangan Terhadap Return saham pada Perusahaan Manufaktur yang Terdaftar di BEI.

S.Soedibjo, Bambang. (2013). Pengantar Metode Penelitian.Universitas Nasional Pasim.Bandung.

Samsul, Mohammad. (2006). Pasar Modal \& Manajemen Portofolio. Jakarta: Erlangga.

Samryn, L. M. (2014). Pengantar Akuntansi.Edisi IFRS. Jakarta: Rajawali Pers.

Siregar, Syofian. (2013). Metode Penelitian Kuantitatif. Jakarta: PT Fajar Interpratama Mandiri.

Syamsudin, Lukman. (2013). Manajemen Keuangan Perusahaan. PT. Gramedia Pustaka Utama. Jakarta.

Tandelilin, Eduardus. (2010). Analisis Investasi dan Manajemen Portofolio. Yogyakarta: BPFE.

Toto, Prihadi. (2010). Analisis Laporan Keuangan. Ppm Manajemen, Jakarta.

Zunaini, Elis., dan Brahmayanti, Ida Ayu Sri. (2016). Pengaruh Rasio Likuiditas diukur dengan CR, QR dan Rasio Pofitabilitas diukur dengan ROA, ROE terhadap Return Saham di Perusahaan Otomotif periode 2012-2014 di BEI. JEM17. Vol. 1 No. 1 Mei 2016.

Zulfikar, (2016). Pengantar Pasar Modal dengan Pendekatan Statistika. Yogyakarta: Deepublish.

http://www.idx.co.id

http:// www.astra-agro.co.id 